\title{
O genius loci w muzeum regionalnym. Czego nam jeszcze trzeba w muzeach lokalnych światów?
}

\author{
About Genius Loci in Regional Museum. What Else Do We \\ Need in the Museums of Local Worlds?
}

Współczesność postawiła przed nami wiele wyzwań, wśród których ostatnimi czasy na czoło wysuwają się zmiany klimatyczne, zagrożenie epidemiologiczne, a także transformacje rozumienia miejsca i roli pełnionej przez człowieka w świecie. Relacje, w które ludzie wchodzą z technologią, rzeczami, a także (a może przede wszystkim) ze zwierzętami i środowiskiem naturalnym, zmieniają się, a wraz z nimi zmieniają się hierarchie ważności i dotychczasowe sposoby rozumienia zależności między nami. Przeobrażenia dotykają także sfery społecznej, a przypominanie o postępującej laicyzacji jednych i/lub radykalizacji innych u progu trzeciej dekady XXI w. pobrzmiewa banałem. Rośnie świadomość obywatelska, poczucie praw jednostki i jej twórczej roli w zbiorowości; można odnieść wrażenie, że coraz bardziej rozwijana jest w nas samych samoświadomość odpowiedzialności i współodpowiedzialności za świat, w którym żyjemy, w jego zmultiplikowanych aspektach. Naszkicowanie nawet bardzo skrótowego i powierzchownego obrazu współczesnego świata w jego wymiarze społeczno-kulturowym, zanurzonym w uwikłania pozaludzkie, nie jest tu celem. Należy jednak zwrócić uwagę na jeden $\mathrm{z}$ aspektów, a mianowicie na zmiany, które można obserwować w obrębie rozumienia pojęcia narodu, które to w szerokich kręgach społeczeństwa zdaje się coraz bardziej tracić na znaczeniu. Współczesny człowiek jakże często czuje się bardziej obywatelem Europy lub wręcz całego globu niż własnego, narodowego państwa. Bezsprzeczne także jest to, że obecnie wiele funkcji państwa narodowego w zakresie decyzji ekonomicznych, politycznych czy kulturalnych delegowanych jest i przejmowanych 
przez regiony. Przynależność do wspólnoty regionalnej może być (i jakże często jest) dla człowieka istotnym wyznacznikiem bycia-w-świecie.

Polityka Unii Europejskiej nakierowana jest na regulowanie praw i tym samym na częściowe ograniczanie samodzielności państw członkowskich, a prowadzenie takich zabiegów „paradoksalnie [...] miało na celu przywrócenie wiary w funkcjonalność tych państw". Podobny mechanizm można zaobserwować w politykach państw demokratycznych w Europie dążących do decentralizacji w obrębie poszczególnych sektorów i obszarów do niedawna kontrolowanych przez państwo. Dzieje się to w gruncie rzeczy w zgodzie z założeniami pierwotnego regionalizmu francuskiego, korzeniami sięgającego XIX w. Założenia ideowe regionalizmu bodaj najcelniej ujęte zostały w opinii Charles’a Pierre’a Jean’a Bruna, jednego z prominentnych przywódców ruchu regionalistycznego, który pisał: „Francja w swej doskonałej jedności przedstawia niezaprzeczalnie mozaikę ras, klimatu, gleby, kultury i temperamentów ludzkich; regionalizm usiłuje to wszystko poznać i wzbudzić poszanowanie dla różnorodności regionalnych".

Regionaliści francuscy, a potem inni naśladowcy europejscy, koncentrowali się przede wszystkim na kwestiach swobody ekonomicznego rozwoju podmiotów w regionach, podziału spraw publicznych na poszczególne szczeble terytorialne. Podkreślano konieczność decentralizacji życia kulturalnego i edukacji. Dzięki rozwojowi życia gospodarczego, politycznego i kulturalnego w poszczególnych regionach miała nastąpić emancypacja prowincji, wzrost świadomości wartości tkwiących w najbliższym otoczeniu oraz budzenie aspiracji i dążeń do rozwoju.

Realizacja kulturalnej emancypacji prowincji była możliwa dzięki powstającym wówczas instytucjom o charakterze kulturalnym, naukowym czy edukacyjnym. Swój udział miały w tym dziele także muzea, które na ziemiach polskich w początkowym okresie ich istnienia w XIX w. nazywano muzeami lokalnymi, prowincjonalnymi lub terytorialnymi. Z czasem, wraz z rozwojem ruchu krajoznawczego, muzea zaczęto określać jako krajoznawcze. Wreszcie potrzeba zdefiniowania terenu, którego historia, kultura i warunki naturalne reprezentowane są $\mathrm{w}$ muzeum, ugruntowała nazwę „muzeum regionalne” funkcjonującą do dziśs.

Namysł teoretyczny nad tym, jakie funkcje ma pełnić muzeum regionalne, obecny jest niemal od początku rozwoju polskiej myśli muzeologicznej.

I K. Jaskułowski, Regiony a państwa w Unii Europejskiej. W stronę państwa postwestfalskiego?, „Spotkania Europejskie” 2009, nr 2, s.35.

2 Ch.P.J. Brun, Regjonalizm francuski, [w:] Ruch regionalistyczny w Europie, red. A. Patkowski, Warszawa 1934, s. 273.

3 Por. F. Midura, Muzea regionalno-krajoznawcze, „Muzealnictwo” 200I, t. 43, s. II3-I2I. 
W wydanej po raz pierwszy w 1917 r. (a wznowionej dzięki staraniom NIMOZ w roku 20194) ważnej pracy Muzea wspótczesne Mieczysław Treter dokonał próby uporządkowania muzeów polskich według kryterium gromadzonych i udostępnianych zbiorów. Pisząc o muzealnictwie krajoznawczym, M. Treter dostrzegal potrzebę stworzenia w każdym muzeum dwóch działów: przyrodniczego - obrazującego „ziemię wraz z przyrodą martwą i żywą”, oraz historyczno-społecznego, w którym przedstawianoby „człowieka współczesnego i dawnego, dzieła jego rąk i wytwory jego ducha”s. W tej atmosferze starano się budować kolekcje muzealne i gromadzono okazy mające unaocznić warunki naturalne i historię/kulturę danego regionu. Niestety, niejednokrotnie muzea regionalne stawały się miejscami nadmiernego gromadzenia przedmiotów, które nie zawsze powinny znaleźć się w zbiorach. W wydanej w $1928 \mathrm{r}$. pracy zbiorowej Cele $i$ zadania muzeów regionalnych przeczytać można postulat, który dość dobrze ilustruje sposób gromadzenia zbiorów w muzeach: „Otrząsnąć się jeno musimy z myśli, że muzeum to - zamknięte pomieszczenie, w którem bywają składane wszelkie wycofane z obiegu życia przedmioty"6. Taki rodzaj kolekcjonowania pokutuje do dziś i próżno by szukać na stronach internetowych muzeów regionalnych ściśle określonych i sformułowanych polityk gromadzenia zbiorów. Postulat tworzenia w muzeum świadomie budowanej, przemyślanej kolekcji wydaje się pierwszym krokiem, który należałoby spełnić, by muzea stawały się coraz bardziej żywymi, prężnymi placówkami działającymi na rzecz wzmacniania poczucia wartości danego regionu.

Odpowiedzi na pytanie, co powinno znaleźć się w kolekcji muzeum regionalnego, należy szukać przede wszystkim w uświadomieniu sobie celów tego rodzaju muzealnictwa. Muzea powinny, podobnie jak inne instytucje kultury i edukacji, pozostawać w dialogu z otoczeniem. Nie mogą być zamkniętymi za murem wyspami historii i patyny, tylko powinny podejmować zadanie żywego reagowania i prób poszukiwania odpowiedzi na pytania, które stawia przed nami szybko zmieniający się świat. Wprawdzie już we wspomnianej pracy w 1928 r. autorzy pisali, że „życie ludzkie wzmaga się wciąż w sile swego napięcia; staje się ono coraz bardziej złożone, lecz zarazem - coraz bardziej trudne do zrozumienia i ogarnięcia dla jednostki" dramatycznie zintensyfikowały, szczególnie w związku z powszechnością Internetu. Człowiek mający dostęp do Internetu może być konsumentem

4 M. Treter, Muzea wspótczesne, (Kijów 1917) Warszawa 2019.

5 Tamże, s. 47-48.

6 Cele izadania muzeów regjonalnych, [w:] Muzea regjonalne. Ksiązka zbiorowa, t. I, oprac. zbiorowe, Warszawa 1928 , s. 7 .

7 Tamże, s. I. 
niemal wszystkich zasobów informacyjnych ludzkości. Największa bodaj trudność w uchwyceniu tego, jaki jest współczesny świat, polega na dostępie do niespotykanej dotychczas różnorodności, bogactwie treści wynikających z momentalnego przepływu informacji. Jak odróżnić rzeczy istotne od tych, które nie wywierają wpływu na kształtowanie kultury i społeczeństwa, gospodarki i środowiska? Jakże często nasz odbiór jest bardzo powierzchowny, nie rozpoznajemy tego, co tkwi u podstaw wytworów kultury: wartości, znaczeń, kulturowych założeń i prawd. Może to być przyczyną ubóstwa przetwarzanych przez nas treści, nieporozumień i naskórkowego rozumienia kultury. Muzeum wydaje się miejscem, dla którego imperatywem powinno być właśnie odszukiwanie ukrytych sensów i znaczeń, poszukiwanie istoty rzeczywistości i wartości, które ją kształtują. Muzeum regionalne zaś robić to powinno w odniesieniu do kultury właściwej dla terytorium działania, które określone jest w dokumentach założycielskich (statucie nadanym przez Ministra Kultury i Dziedzictwa Narodowego). To właśnie w muzeach możemy zrozumieć, jaki sens i znaczenie dla autochtonicznej ludności miały artefakty pełniące dziś rolę pamiątek i elementów domowego decorum. Muzea odkrywając wartości tkwiące u podstaw tworzenia i użytkowania artefaktów stają się pośrednikami pomiędzy ludźmi rozmaitych kultur: w wymiarze etnicznym, ale także i w wymiarze personalnym, międzyosobowym. Czyż zrozumienie na przykład grup subkulturowych na danym terenie nie może stanowić pierwszego kroku do budowania mostów pomiędzy ludźmi, którzy pozornie są odlegli i nie do pogodzenia? Paręnaście lat temu w Muzeum Historycznym Miasta Krakowa odbyła się wystawa ilustrująca losy dwóch zwyczajowo zwaśnionych klubów sportowych z Krakowa. Zgromadzone tam obiekty ilustrowały pewną paralelność historii, pasji i wartości. Wystawa opatrzona została wydawnictwem ${ }^{8} \mathrm{i}$ była odwiedzana przez kibiców obu drużyn. Nie zostały opublikowane żadne badania, które wskazywałyby na to, że wystawa stała się przełomem w relacjach pomiędzy zantagonizowanymi grupami kibiców. Jednak koniecznie należy podkreślić, że wydarzenie to było na pewno jedną z pierwszych prób w muzealnictwie polskim zmierzenia się z problemem i dążenia do otwarcia na wzajemne zrozumienie. Muzea mogą tu być realizatorem myśli regionalistycznej w zakresie, w którym Roman Szul opisywał regionalizm europejski jako zjawisko pozytywne, podkreślając, że miał on być „przeciwwagą dla destrukcyjnego nacjonalizmu, utrudniającego współpracę między narodami i hamującego integrację europejską" ". Przyczynienie się do przełamywania stereotypów i niwelowania napięć pomiędzy

8 Święta wojna-święta zgoda, red. A. Kutylak, Kraków 2006.

9 R. Szul, Regionalizm w Europie. Czynniki i ewolucja, „Mazowsze. Studia Regionalne” 20I3, nr I2, s. I3I. 
tymi częściami społeczności, które z różnych powodów pozostają w konfliktach, tym samym dążenie do harmonijnego koegzystowania lokalnych odmienności kulturowych może być traktowane jako jeden z istotnych celów funkcjonowania muzeów regionalnych.

Jedną z cech globalizacji kultury jest również wszechobecne zagrożenie, którego istnienie nie wymaga odrębnego dowodzenia, czyli zagrożenie unifikacją kultury. Globalne firmy produkcyjne wytwarzające odzież czy żywność, licencje na programy telewizyjne, ujednolicenie sposobów komunikowania w Internecie. Przykładów szczegółowych jest tak wiele, że nie sposób ich wymieniać. Korzystamy z tych wszystkich globalnych osiągnięć cywilizacji bardzo często dość bezrefleksyjnie, jak wcześniej zostało wspomniane - w trybie dość powierzchownej konsumpcji. Homogenizacja wzorów i stylów życia, wzrastająca mobilność wynikająca z ekonomicznych lub społecznych przesłanek może być i jakże często jest przyczyną zaniku i niepewności tożsamości. I tutaj pojawia się kolejne ważne zadanie dla muzeów. Zbiory muzealne i przekazywane przez nie treści mogą być istotnym i ważnym czynnikiem budowania lokalnej tożsamości dla miejscowych i zasiedziałych mieszkańców, ale także przestrzenią, gdzie można znajdować pola jej re-kreacji w nowym dla siebie miejscu. Jak podkreśla wspomniany już R. Szul: „różnice etno-kulturowe, w stosunku do innych regionów kraju, mogą zrodzić poczucie inności wobec otoczenia, poczucie odrębnej tożsamości regionu i chęci utrzymania, wzmocnienia lub demonstrowania tej tożsamości” ${ }^{1 \circ}$. R. Szul zwraca również uwagę na waloryzację odróżniających region cech i fakt, że „niezbędne jest, by cechy te były uważane za istotne i pozytywne, tj. godne zachowania i demonstrowania. Jeśli jakaś cecha [...] jest uważana za nieistotną, a tym bardziej za wstydliwą (np. znamionującą zacofanie) to mieszkańcy regionu bardziej będą skłonni pozbyć się jej [...] niż ją zachowywać i eksponować" "To, co ekonomista pisze o cechach kulturowych, można odnieść również do kwestii zbiorów w muzeach regionalnych.

Tim Dant stwierdza we wstępie do swych rozważań na temat kultury materialnej: „świat rzeczy wytworzonych przez człowieka zmienia świat przyrody i stwarza środowisko materialne, które stanowi kontekst interakcji społecznej. Rzeczy, wytwory zarówno natury, jak i człowieka, są wpisane w ludzką kulturę w taki sposób, że reprezentują stosunki społeczne wewnątrz kultury, zastępując innych ludzi, przenosząc wartości, idee i uczucia" ${ }^{\text {I2 }}$ W działalności kolekcjonerskiej muzeum regionalnego można zaproponować spojrzenie niejako z drugiej strony. Pierwszym tro-

\footnotetext{
Io Tamże, s. II5.

II Tamże.

I2 T. Dant, Kultura materialna w rzeczywistości spotecznej, Kraków 2007, s. I3.
} 
pem miałoby tu być poszukiwanie wartości i idei istotnych dla społeczności, we wszystkich obszarach charakteryzujących jej kulturę, a następnie pozyskiwanie do kolekcji takich obiektów, które są najlepszą ich ilustracją.

Co wydaje się bardzo istotne w odniesieniu do wspomnianych konstatacji R. Szula, to fakt, że z przyczyn oczywistych zarządzający muzealnymi kolekcjami dążą do zachowywania pamiątek po przeszłości, która chce być zapamiętana, która jawi się w historii jako „świetlana”. Nie ma w muzeach i na wystawach śladów po historii, która jest „ciemna”, wstydliwa i nieprzynosząca chluby. Ale być może nadszedł czas, by rozszerzyć zakres budowanej kolekcji także i o abiekty - pojęcie zaproponowane przez Julię Kristevą dla obszaru refleksji filozoficzno-psychoanalitycznej, zaś na grunt refleksji historycznej przeszczepiony przez Ewę Domańską ${ }^{13}$. Według E. Domańskiej, przeniesienie punktu ciężkości polegać ma „na włączeniu do oficjalnego dyskursu historycznego tych wszystkich, których historia tradycyjnie bądź to wypierała, bądź też przedstawiała ze swojego punktu widzenia (tubylcy, kobiety, kalecy, dzieci, zwierzęta, rzeczy)"I4. W muzeum regionalnym może się to wyrazić poszerzeniem pola zainteresowań w ramach tworzenia muzealnej oferty. Należy pamiętać o Innych: mniejszościach etnicznych, narodowych, ale także seksualnych, o grupach odrzuconych, subkulturach i kontrkulturach, o jednostkach wybitnych i tych, które tylko w nieznaczny sposób wpisują się w „regionalny ekosystem”. Włączenie w narracje muzealne grup do tej pory wykluczanych sprawić może, że historia pokazywana na wystawie stanie się historią wszystkich zainteresowanych graczy tworzących tkankę kultury zarówno tej dawnej, jak i współczesnej. Kultura w regionie jest swoistym palimpsestem i odkrywanie jej kolejnych warstw jest zgodne z postulatem „zstępowania do głębi” i poszukiwania ukrytych sensów, znaczeń, wartości, by (możliwie) w pełni zrozumieć świat przed podejmowaniem prób zmieniania go. W tym momencie znowu można sięgnąć do wydanej niemal sto lat temu pracy o muzeach regionalnych, którym wyznaczono ambitny cel zawarty w tytule wprowadzającego tekstu Artura Górskiego: O stużeniu Prawdzie $e^{15}$. Autor pisze tu wręcz, że ,świadomość prawd jest konieczną w życiu zbiorowem. Los narodu, opartego o błąd w zasadniczych prawach bytu, jest straszny, jeszcze groźniejszy jest los społeczeństwa, które się zakłamało w życiu, dopuściwszy do rozłamu pomiędzy świadomością prawdy a życiem. Człowiek w ogóle rozpoczyna się dopiero wtedy, gdy szuka prawdy, gdy jej pragnie"16.

I3 E. Domańska, Historie niekonwencjonalne, Poznań 2006, s. 94-I03.

I 4 Tamże, s. ıoo.

I5 A. Górski, O stużeniu Prawdzie, [w:] Muzea regjonalne..., s. 17-26.

I6 Tamże, s. 17-18. 
Dziś jesteśmy skłonni myśleć raczej o wielu „prawdach” niż o jednej, obowiązującej, ale postulat dążenia do odkrywania i odsłaniania kolejnych warstw kulturowego palimpsestu i różnych prawd pozostaje w mocy. Dzięki temu bowiem kultywujemy pamięć o poprzednich pokoleniach, chronimy dziedzictwo, a przez to możemy zrozumieć się lepiej. Jako swoiste dopełnienie można potraktować zdanie wspomnianego już Ch.P.J. Bruna, który upominając się o konieczność decentralizacji, podkreślał, że „jednostajność nie stanowi o jedności, jest ona tylko jej pospolitym falsyfikatem"17.

Wymagać to może jednak poszerzenia uczestników konsultacji w sprawach dotyczących budowania kolekcji i jej upowszechniania. Wynika z tego postulat zachowywania postawy otwartości na inność i czujności w rejestrowaniu zmian społeczno-kulturowych (choć także i tych związanych ze środowiskiem naturalnym) przez pracowników muzeum. Już w 1928 r. postulowano: „Muzeum regionalne utrzymuje w ewidencji wszelkie istniejące w okręgu muzealnym ruchome i nieruchome zabytki przyrody i kultury, będąc w styczności z odpowiednimi instytucjami państwowymi i społecznymi, których zadaniem jest ochrona tych zabytków"18. Współczesność otwiera wiele nowych możliwości ewidencjonowania obiektów kultury - zarówno materialnej, jak i niematerialnej. Dzięki nowym technologiom jesteśmy $\mathrm{w}$ stanie zachować wiele informacji dla przyszłych pokoleń, pytanie tylko, czy to rzeczywiście w muzeach jest robione? Czy przypadkiem nie tropimy ciągle śladów przeszłości, skupiając się wyłącznie na historii, zamiast sięgać do źródeł współczesnych? W przeprowadzonych w $2014 \mathrm{r}$. badaniach przez TNS Polska ustalono, że zaledwie $35 \%$ badanych Polaków interesuje się historią ${ }^{19}$. Pozostałe dwie trzecie ludności zapewne troszczy się bardziej o swoją teraźniejszość i przyszłość. Czy muzea, które wszak przede wszystkim gromadzą zabytki przeszłości, mogą być dla nich atrakcyjnym i ważnym miejscem kształtowania zainteresowań i wrażliwości? Odpowiedź twierdząca możliwa będzie tylko pod warunkiem otwarcia się muzeów na rzeczywiste problemy nurtujące mieszkańców regionu, zamiast na budowaniu często wyimaginowanej, zmityzowanej wizji przeszłej chwały. I znowu można sięgnąć do opracowania z 1928 r., w którym autorzy postrzegają funkcję muzeum regionalnego, które powinno spełniać „rolę wychowawczą, dając człowiekowi podstawy właściwego postępowania wynikające z dostrzegania własnej jego roli i znaczenia na ziemi i w życiu narodu"20. Czas, kiedy powstawała

17 Ch.P.J. Brun, dz. cyt., s. 273.

I8 Cele izadania..., s. II.

19 https://www.newsweek.pl/polska/sondaz-znajomosc-dat-zainteresowanie-historia-newsweekpl/ hjgfmfw [dostęp: 6 marca 2020].

20 Cele izadania..., s. 12. 
cytowana praca, czyli okres międzywojenny, był etapem odbudowywania państwa po okresie zaborów we wszystkich jego przejawach, także w zakresie kultury. Współcześnie należałoby zapewne uzupełnić ten katalog o obszar kultury/społeczeństwa europejskiego czy wymiaru globalnego, ale także o struktury czy sieci ponadnarodowe, zarówno formalne, jak i nieformalne.

Fakt przywołania po raz kolejny opracowania sprzed niemal stu lat i dostrzeżenie aktualności sformułowań weń zawartych świadczyć może, z jednej strony, o pewnej ponadczasowości mądrych spostrzeżeń autorów, z drugiej zaś o tym, że - jak widać - muzealnicy niezbyt sobie je wzięli do serca. Wprawdzie zdarza się, że w muzeach poruszane są tematy bieżące, ale ciągle jeszcze bardziej interesuje nas patyna historii niż współczesność z jej bogactwem także mniejszościowych tematów.

Muzeum, które ewidencjonuje kulturę w rozmaitych jej przejawach i upowszechnia wyniki prowadzonych badań, staje się miejscem, które może być dla niemal każdego przestrzenią przyjazną, otwartą i współtworzącą poczucie własnej odrębności i tożsamości opartej na wyznawanych wartościach. Dzięki temu wzrasta jego kulturotwórcza rola, a poprzez edukację adresowaną do bardzo różnych grup społecznych muzeum może budować świadomość i odpowiedzialność obywatelską. Budowanie wymiaru wspólnotowego owej obywatelskiej odpowiedzialności za świat-w-którym-żyjemy należy traktować jako ważne zadanie dla pracowników muzeów regionalnych. Zgodne jest to $\mathrm{z}$ definiowaniem regionalizmu rozumianego jako „tendencja promowania wartości wspólnot ludzkich”"2 istotnych dla budowania tożsamości wokół założeń rozwoju i bycia w drodze ku przyszłości.

Warunkiem osiągania sukcesów w drodze ku przyszłości jest, wspominane w 1928 r., nawiązanie współpracy z ,instytucjami państwowymi i społecznymi”. Muzeum regionalne zawieszone jest $\mathrm{w}$ sieci współistniejących $\mathrm{z}$ nim w regionie instytucji i organizacji. Są to przede wszystkim inne organizacje działające w obszarze wolnego czasu związane z kulturą, sportem, rekreacją, ale także organizacje edukacyjne, biblioteki, centra kultury, jak również parafie. Nad wszystkim czuwać powinny i sprawować pieczę władze publiczne, których naczelnym zadaniem jest służba społeczeństwu i jego agendom, czyli także muzeom. Jednym z podstawowych zadań muzeum regionalnego powinno być mapowanie regionu i nawiązywanie maksymalnie wielu relacji zinnymi organizacjami działającymi na tej samej niwie, a więc w zakresie edukacji, upowszechniania kultury, zagospodarowywania czasu wolnego itp. Można postulować, by muzea przestały traktować inne instytucje kultury i edukacji jako swoich

2I A. Chodubski, Idea i praktyka nowego regionalizmu a globalizacja cywilizacji, [w:] Regionalizm a globalizacja. Polska - Unia Europejska oraz inne zjawiska i procesy regionalne świata, red. A. Chodubski i in., Gdańsk 2007, s. I4. 
konkurentów, a zamiast tego by dążyły do stworzenia platformy porozumienia, na której dzięki ich współdziałaniu człowiek współczesny może poszukiwać odpowiedzi na niepokojące go pytania. Sieci powiązań, które tworzyć może wokół siebie muzeum, mogą dla współczesnych i przyszłych pokoleń być nadzieją na to, że nie zagubi się w natłoku informacji i powierzchownych treści.

Sieciowanie i tworzenie nowych relacji należy również postulować w obrębie działań muzealnych w obszarze interpretacji i upowszechniania zbiorów. Z jednej strony, trzeba zwrócić uwagę na potrzebę konsultowania możliwości interpretowania dzieł przez grupy zainteresowane, na przykład grupy mniejszościowe, użytkowników czy spadkobierców. $Z$ drugiej, bardzo istotny jest postulat interdyscyplinarności i otwierania możliwości interpretowania dzieł $\mathrm{z}$ różnych perspektyw, także teoretycznych. Wydaje się, że muzea regionalne są szczególnie predystynowane do interdyscyplinarności, z założenia bowiem znajdują się w nich działy, które poświęcone są bardzo odległym dyscyplinom naukowym. Poszukiwanie związków pomiędzy działem przyrodniczym, archeologicznym czy historycznym jest możliwe, jeśli przyjmie się założenie, że łącznikiem jest przyszły lub obecny mieszkaniec danego regionu. Realizacja założeń poszukiwania wielu ciągle odsłaniających się prawd i interdyscyplinarnych sposobów zrozumienia człowieka stawia muzeum regionalne jako placówkę realizującą w pełni ideały humanistyczne.

Należy wskazać jeszcze i jeden aspekt działania muzeum regionalnego, który może stać się istotnym atutem działającym na rzecz rozwoju tego typu muzealnictwa. Otóż wydaje się, że inspirujące dla tego typu muzealnictwa byłoby myślenie o muzeum przez pryzmat genius loci. Pojęcie „ducha miejsca” w pierwotnym znaczeniu poświęcone było szczególnej atmosferze danego miejsca, odniesieniu do jego wyjątkowości i tożsamości. Janusz Grycel, cytując Christiana Norberg-Schultza, stwierdził, że „można mówić o silnym, niepowtarzalnym charakterze jakiegoś miejsca, determinującym podstawowe cechy obrazu otoczenia w obecności większości obecnych tam ludzi lub konkretnej rzeczywistości, której człowiek musi stawić czoła i zaakceptować w swoim codziennym życiu" ${ }^{22}$. Odkrywanie owego genius loci jawi się jako imperatyw dla muzeum regionalnego w co najmniej dwóch obszarach.

Z jednej strony, chodzi o to, by odkrywać ową ,indywidualną jakość", która nadana jest przez ducha miejsca ${ }^{23}$. Składają się na nią liczne cechy i właściwości, które są wypadkową tego, jacy ludzie zamieszkują dany obszar, jak kształtowała się historia, jakim wydarzeniom należało stawiać czoła, a ja-

22 J. Grycel, Duch miejsca odczytany na nowo, „Czasopismo Techniczne. Architektura” 2oro,

R. 107, z. 15, s. 95.

23 Por. K. Dąbrowska-Budziło, Genius loci jako potencjalne źródto inspiracji dla ksztattowania

krajobrazu, „Prace Komisji Krajobrazu Kulturowego PTG” 201I, nr I5, s. 228. 
kie były dla mieszkańców regionu szczęśliwym trafem... Architekci często podkreślają konieczność uwzględniania ducha miejsca w projektowaniu ${ }^{24}$, szczególnie zwracając uwagę, że jeśli zaniecha się wykorzystywania ducha miejsca jako inspiracji w projektowaniu przestrzeni, może nastąpić „zatarcie warstwy znaczeniowej krajobrazu oraz jego unifikacja" ${ }^{25}$. Dzięki wykorzystaniu genius loci, według Krystyny Dąbrowskiej-Budziło, możemy ochronić krajobraz przed zatratą indywidualnych cech. Czyż takich samych wniosków nie należy wysnuć w odniesieniu do krajobrazu kulturowego? Czyż ujednolicenie kultury nie jest zagrożeniem (o którym już była mowa, a do którego prowadzić może globalizacja), któremu należy się przeciwstawiać? Muzeum może więc brać udział $\mathrm{w}$ świadomym $\mathrm{i}$ konsekwentnym poszukiwaniu istoty owego ducha miejsca, podejmowaniu prób odkrywania kolejnych warstw kulturowego palimpsestu i dokonywania rekonstrukcji czegoś, co można by (roboczo) określić jako „przepis na kulturę lokalną”. I to właśnie stanowić winno program gromadzenia zbiorów w muzeum oraz ich udostępniania i upowszechniania na rozmaite charakterystyczne dla muzeum sposoby.

Należy tu wszakże pamiętać nie tylko o tych elementach kultury, które pochodzą z najmocniejszego, „większościowego” obszaru, ale także o tych drobnych, pozornie nieistotnych „mniejszościowych” elementach. Jak podkreśla Stefan Symotiuk, „tak jak o trwaniu łańcucha nie decyduje jego ogniwo najmocniejsze, ale najsłabsze, tak o życiu ludzi i kultur decydują często elementy zgoła błahe, acz niezbywalne" ${ }^{26}$. Filozof postuluje uprawianie „mikrofilozofii”, której przedmiotem badań byłoby:

ustalanie sytuacji ludzkich i kulturowych, w których szczegót i drobiazg zawęźlają się z momentem procesu, tworząc pospołu układ czasowo-przestrzenny. [...] przez mikrofilozofię rozumieć więc trzeba mądrość, jaka dana jest nam w odczytaniu sytuacji niepowtarzalnej i jednocześnie kluczowej. Każde miejsce i sytuacja mająklucz do siebie - a klucz ten, jak w naszych zamkach do drzwi, jest inaczej perforowany ${ }^{27}$.

Można tu postulować jakiś rodzaj „mikromuzealnictwa”, takiego rodzaju patrzenia na obszar zainteresowań danego muzeum, który uwzględni niepowtarzalność najmniejszych drobiazgów, które wszak stanowią o kulturze, ergo: o życiu regionu. Nie bójmy się w muzeach regionalnych dokumen-

\footnotetext{
24 Por. Tamże; J. Grycel, dz. cyt.; M. Pożarowszczyk, Identyfikacja Genius Loci - krok w strone piękna, „Metropolitan” 20I 4, nr I, s. 28-3I; Ch. Norberg-Schultz, Genius Loci. Towards a Phenomenology of Architecture, New York 1979.

25 K. Dąbrowska-Budziło, dz. cyt., s. 228.

26 S. Symotiuk, Filozofia i Genius Loci, Warszawa 1997, s. 7.

27 Tamże.
} 
tować i opowiadać historii zwykłych ludzi, także ciemnych stron ich życia. Nie tylko bohaterowie, nie tylko czyny chwalebne, nie tylko najpiękniejsze efekty najważniejszych osób stanowią o tym, jacy jesteśmy, jak kształtują się owe perforacje, które otwierają nas na nas samych, pokazują naszą wyjątkowość i tożsamość. „Szczegół i drobiazg” mogą uratować nasze jestestwo zagrożone rozmyciem w morzu jedno-jakości.

Nie oznacza to, że postuluje się tu swoisty wszystkoizm i tworzenie kolekcji „wszystkiego co się da”. Bardzo często w historii muzealnictwa tak właśnie było, a już w 1928 r. autorzy wspominanej wielekroć książki zbiorowej przestrzegali, że muzea „powinny jak najprędzej stracić dotychczasowy charakter rupieciarni, lub co najwyżej magazynów muzealnych" ${ }^{28}$. Muzeum regionalne (podobnie zresztą jak każde inne) nie powinno w żadnym wypadku zamieniać się w magazyn zbiorów. Dzięki podejmowanym działaniom upowszechnieniowym, dzięki udostępnianiu zbiorów w możliwie szeroki sposób - biorąc oczywiście pod rozwagę względy konserwatorskie i bezpieczeństwa - muzea stawać się mogą coraz bardziej tętniącymi życiem miejscami współtworzenia i pielęgnowania tożsamości lokalnej. Postrzeganie ich jako istotnych instytucji kulturotwórczych pełniących ważne społeczne role będzie równoznaczne z tym, że muzea regionalne mogą być (i zapewne często są) doniosłymi składowymi owego genius loci, dzięki któremu świat-w-którym-żyjemy staje się lepszym miejscem do życia. A czyż ostatecznym rozrachunku nie o to właśnie chodzi?

\section{Bibliografia}

\section{Opracowania}

Brun Ch.P.J., Regjonalizm francuski, [w:] Ruch regionalistyczny w Europie, red. A. Patkowski, Warszawa 1934.

Cele i zadania muzeów regjonalnych, [w:] Muzea regjonalne. Książka zbiorowa, Warszawa 1928.

Chodubski A., Idea i praktyka nowego regionalizmu a globalizacja cywilizacji, [w:] Regionalizm a globalizacja. Polska - Unia Europejska oraz inne zjawiska i procesy regionalne świata, red. A. Chodubski i in., Gdańsk 2007.

Chudziński E., Regionalizm. Idea - realizacje - instytucje, Warszawa 2010.

Dąbrowska-Budziło K., Geniusloci jako potencjalne źródto inspiracji dla ksztattowania krajobrazu, „Prace Komisji Krajobrazu Kulturowego” 2011, nr I5.

Dant T., Kultura materialna w rzeczywistości spotecznej, przeł. J. Barański, Kraków 2007.

Domańska E., Historie niekonwencjonalne, Poznań 2006.

Grycel J., Duch miejsca odczytany na nowo, „Czasopismo Techniczne. Architektura” 2010, R. 107, z. 15.

Jaskułowski K., Regiony a państwa w Unii Europejskiej. W stronępaństwa postwestfalskiego?,

„Spotkania Europejskie" 2009, nr 2.

Midura F., Muzea regionalno-krajoznawcze, „Muzealnictwo” 200I, t. 43.

28 Cele izadania..., s. 8. 
Muzea regjonalne. Książka zbiorowa, t. I, Warszawa 1928.

Norberg-Schultz Ch., Genius Loci. Towards a Phenomenology of Architecture, New York 1979. Pożarowszczyk M., Identyfikacja Genius Loci - krok w stronę piękna, „Metropolitan” 20I4, nr I. Symotiuk S., Filozofia i Genius Loci, Warszawa 1997.

Szul R., Regionalizm w Europie. Czynniki i ewolucja, „Mazowsze. Studia Regionalne” $2013, \mathrm{nr} 12$. Święta wojna - święta zgoda, red. A. Kutylak, Kraków 2006.

Treter M., Muzea wspótczesne, (Kijów 1917) Warszawa 2019.

\section{Strony internetowe}

https://www.newsweek.pl/polska/sondaz-znajomosc-dat-zainteresowanie-historia-newsweekpl/hjgfmfw

Streszczenie: Artykuł prezentuje nowe spojrzenie na znaczenie i funkcje muzeum regionalnego wobec zmian mających miejsce w świecie współczesnym. Zmiany te dotyczą samej filozofii człowieka, którego rola coraz mniej postrzegana jest w kategoriach supremacji wobec środowiska naturalnego, a coraz bardziej relacji równorzędności. Dalej, ma miejsce pomniejszanie roli państwa narodowego na rzecz społeczeństwa globalnego, poszerzając zarazem przestrzeń dla lokalizmów kulturowych, w tym regionalnych i mniejszościowych. Lokalizmy z kolei wykraczają poza sferę etnosu, obejmując swym zasięgiem podziały kulturowe z porządku typologicznego. Kryteria opisu osobliwości kulturowych wychodzą poza ramy afirmacji własnego dziedzictwa, skupiając się zarazem na jego ciemnych stronach. Te i inne procesy pociągają konieczność redefinicji misji muzeum regionalnego, którego wszak naczelnym zadaniem pozostaje eksponowanie genius loci, ducha miejsca, w którym muzeum funkcjonuje i którego ma wyrażać.

Słowa klucze: muzeum regionalne, genius loci, społeczność lokalna, mniejszości w muzeum, w poszukiwaniu tożsamości

Summary: The article presents a new understanding of the meaning and functions of a regional museum in the face of changes taking place in the contemporary world. These changes concern the very philosophy of man, whose role is less perceived in terms of supremacy over the natural environment, and more in terms of equality. Next, the role of the nation-state is diminished for the benefit of the global society, at the same time expanding the space for cultural localisms, including regional and minority ones. Localisms, in turn, go beyond the sphere of ethnos, embracing cultural divisions of the typological order. The criteria for describing cultural peculiarities go beyond the affirmation of one's own heritage, while focusing on its dark sides. All of these and other processes make it necessary to redefine the mission of a regional museum, the main task of which, after all, is to display the genius loci, the spirit of the place where the museum operates and which it aims to express.

Keywords: regional museum, genius loci, local community, minorities in the museum, in search of identity 